\title{
Factoral Analysis of the Financial Leverage of the Enterprise
}

\author{
Izolda Chiladze \\ Correspondence: Izolda Chiladze, Department Accounting, and Audit, Ivane Javakhishvili Tbilisi State University, \\ Tbilisi, 0179, Georgia.
}

Received: December 11, 2018

Accepted: January 22, 2019

Available online:February 15, 2019

doi:10.11114/afa.v5i1.4063

URL: https://doi.org/10.11114/afa.v5i1.4063

\begin{abstract}
The activities of the enterprises always involve some uncertainty, therefore there is always a risk that objectives may not be achieved. So, theoretical and practical aspects of business risks are always relevant. The goal of the research is to select the general indicator of the financial risk between the leverage coefficients of the enterprises and to create its' factorial model. The subject of research is the system of financial leverage ratios of the enterprise. Financial information on Georgian wine companies is used for the practical provision for research.

As a result of the research has been created a new factor model of the general indicator of financial leverage. It is possible to measure five-factor indicators making an impact on the level of financial leverage. Its regular analysis will help enterprise management to fully control and manage the financial risks of the enterprise, to implement adequate measures on the basis of which the financial stability of the enterprise would not be jeopardized, which is also in the public interest.
\end{abstract}

Keywords: business risks, risk indicators, financial leverage, a factorial model

\section{Introduction}

\subsection{Risks and Business}

Generally, the risk is the probability that goals may not be achieved. 'Business is always at risk, as obtaining the expected results is not clearly known, they are not defined. Companies always have to work in the conditions of uncertainty because there always exists some probability that the goals of the company may not be achieved, and that that the process of achieving these goals is accompanied by the risk of failure. Therefore, the theoretical and practical research of ways of reducing risks and avoiding anticipated additional expenses is very important and at the same time rather problematic"(Izolda Chiladze. 2017). The acuteness of the problem of the above mentioned is conditioned by the fact that it is difficult to determine and count the losses of the company caused by risk. The risk may not appear in the current year, but the financial results of the enterprise will be destructive in the next year and management will not meet them fully prepared. Management is responsible for implementation and monitoring of the risk management process and incorporating it into the day to day activities of the company (Yinka M. Salaudeen, Taibat A. Atoyebi, and Bamidele A. Oyegbile. 2018). The reason for such events is that often the managers of the enterprises do not supervise risks because making risk evaluations are often impossible. But, it is possible to measure risks using probability and statistical methods. Consequentcorrect selection and assessment of the risk indicators of the enterprises and its factor analysis involve a laborious process. It should be noted that on the enterprise's economical results affect the external riks too, but they will not be considered here because it is separate research.

\subsection{Classification of Business Risks}

Many types of risks are known in economic literature. Classification of business risks is grouped according to the uniform signs. In our opinion, the risks of enterprises can be grouped as follows:

\section{External risks:}

a. Regardless of human activity - the risks of natural disasters;

b.Depending on human actions - the risks of political, legislative and economic character at the national and international levels.

II. Internal risks:

a. Production risks, such as resources risk, costs risk, assets risk, technological risk, etc. 
c.Financial risks, related to risks of financing sources, changes in exchange rates, purchasing and selling of securities, liabilities, interest risks, etc.

d.Managing risks, which is a probability that adequate decisions cannot be taken. Management always carries certain risks when making decisions. But then timely precaution and prompt response are necessary for the risk outcome to become positive.

Due to the fact that there is no business without risks, risk management and minimization of its expected costs are one of the urgent tasks of enterprise management. And the main way to effectively manage risks is their analysis. Enterprise risk analysis includes three interconnected components: risk assessment, factor analysis, and recommendations.

In modern economic theory and practice, leverage ratios are used to assess entrepreneurial risk. There is a difference between operating and financial leveraging coefficients. Leverage generally means the burden of dependence between the two opposite nature things. Operating leverage is related to the existence of permanent operating costs. Operating leverage is also a measure of the quality of the sensitivity of the company's operating profit towards the change of its revenue (sales).

Financial leverage indicates how much business depends on loans. Financial leverage, first of all, demonstrates how the company uses the obligation as a part of the funding strategy. All these lead to the relevance of research on the topics of in-depth analysis of financial leverage. The purpose of this article is to review financial leverage coefficients, selecting the most common indicator and creating its factor model.

\subsection{Literature Review}

Many researchers write about business risks and leverage different directions. Such as Pamela Peterson Drake and Frank J. Faborzzi (2012) review three types of credit risk: default risk, credit downgrade risk and credit spread risk. They write, that Default risk is the likelihood that the issuer of debt is not able to meet the promised obligations to pay interest and repay the obligation. Credit downgrade risk is the risk of an increase in default risk. We refer to this risk as downgrade risk because we often observe that the company`s credit rating is downgraded as default risk increases. The yield of a debt obligation will reflect the debt`s risk, but credit spread risk is the uncertainty that the difference between the yield on a debt instrument and the yield for a benchmark, such as a Treasury bond, will change (p.241-242). Charles H. Gibson (2013) has reviewed the financial leverage of different indicators (p. 272-273).

The interesting researchhaspresentedDilip K. Ghosh, Arun J. Prakashb,\& Dipasri Ghosh (2010). They written: "a special case of this occlusion can be stated as follows: at constant returns to capital - debt and equity - and at constant distortion in the capital market, if debt alone increases (that is equity remains unchanged), relatively levered firm (in physical sense) expands and the less levered firm shrinks" (p. 468). Tomas R. Ittelson (2009) describes ways to minimize risk and uncertainty. James, C., Van Horne, John M. Wachowicz, Jr. (2008)have an operational, financial and, general leveraging ratios how affecting the value of the capital of the enterprise: „Operating leverage and financial leverage can be combined in a number of different ways to obtain the desired degree of total leverage and level of total firm risk. High business risk can be offset with low financial risk and vice versa. The proper overall level of firm risk involves a trade-off between total firm risk and expected return. This trade-off must be made in keeping with the objective of maximizing shareholder value. The discussion, so far, is meant to show how certain tools can be employed to provide information on the two types of leverage - operating and financial - and their combined effect. Subramanyam, K. R., and Joan J. Wild, (2009) are written, that they focus on capital structure and its implications for solvency. We analyze the importance of financial leverage and its effects on risk and return. Analytical adjustments are explained for tests of liquidity and solvency. We describe earnings-coverage measures and their interpretation. Financial leverage refers to the amount of debt financing in a company's capital structure. Companies with financial leverage are said to be trading on the equity. This indicates a company is using equity capital as a borrowing base in a desire to reap excess returns (pp: 544). Business risks are also discussed in his book Ivo Welch, and so on. Thus, many authors write about the coefficients of leverage, But they do not see factor models of financial leveraging.

Thus, as a result of the review of the relevant literature, we found out that the articles on the factor model of the Leverage coefficients are not published. I apologize to the authors whose work is not available to us. The Factor Model of the General Operating Leverage (FC/EBIT) has been developed by us (Izolda Chiladze. 2017. p. 80). And, the purpose of this study is to model the factors of the financial leverage coefficient.

\section{Financial Leverage Conceptual Analysis}

\subsection{Indicators of Business Financial Leverages}

Financial risks are expected to arise as a result of financial deals and changes in foreign exchange rates, in the purchase and selling securities, during the credit risk, such as liabilities timely payment risk, investment risk of issuing dividends, interest expenses coverage risk. Financial leveraging examines the correlation between lending and the own capital of 
the enterprise with the change of profit. Optimization of financing sources structure for the purpose of profit maximization is called the concept of financial leverage.

Financial leverage is used for assessing financial risks. It is especially interesting for shareholders to know how much profit should be expected on every single share. Financial leverage depends on the choice of the enterprise's management, either to use loans to finance, or to issue preference shares or ordinary shares. When the company uses loans or issues preference shares, they always have financial leverage, because there is a constant accrued amount of funds raised, which is the cost of interest for the company. In addition, issued privileged shares are not really a loan, but have a guaranteed dividend and the company is obliged to pay dividends on privileged shares at an unchanged interest rate and only then the dividends will be distributed on ordinary shares. Thus, financial leverage is used to increase the profitability of ordinary shares. Leverage has a direct impact on the change in shareholder return.

In regard to the above, there is a difference between favorable and unfavorable financial leverage.

Favorable or positive financial leverage occurs when the enterprise uses the fixed-rate policy of liabilities of fixed financial expenses and privileged shares dividends in order to earn more than the fixed financial expenses (on rates and dividends) paid. Economists write that the rest of the profits obtained after covering fixed costs for the received fund belong to ordinary shareholders.

Unfavorable or negative financial leverage occurs when the company fails to generate an amount equal to financing constant costs. Thus, the advantage of the financial leverage is determined by the income that it brings to one ordinary share. The following income (earnings) calculation rule is distributed for one ordinary share (EPS):

$$
\mathrm{EPS}=\frac{\mathrm{OP}-\mathrm{P}-\mathrm{TP}-\mathrm{PSD}}{\mathrm{N}}
$$

$\mathrm{OP}$ - operating profit (earnings before interest and tax)

$\mathrm{P}$ - interest expenses

$\mathrm{TP}$ - tax profit

PSD - Privileged shares dividends

$\mathrm{N}$ - The number of ordinary shares

But this indicator may not coincide with the "dividend on one ordinary share" because net profit should also be used to financially stimulate the development of the company and staff. In modern conditions of competition, it became necessary to introduce new technologies and innovative technologies in the field of production and services that require certain finances and should be covered by profits. Therefore, it is not enough to satisfy only the shareholders' financial interests. From the net profit of the company, reserves should be created for business development, risk, personnel, etc. In our opinion, one of the indicators of business sustainability today is the share of reserves created from profits in net profit. Based on the above, the first formula should be corrected as follows:

$$
\mathrm{EPS}=\frac{\mathrm{OP}-(\mathrm{P}+\mathrm{TP}+\mathrm{PSD}+\mathrm{R})}{\mathrm{N}}
$$

$\mathrm{R}$-reserve created from profit.

Financial leveraging coefficients are divided into two groups: Capital leverage and interest leverage. In economic literature, the following coefficients of financial leverage (Fl) are known:

$$
\mathrm{Fl}_{1}=\text { Assets/own capital }
$$

When this ratio is equal to one, then the entire assets are financed by their own capital and there is no financial risk. But if it is more than one, then the enterprise also has funding as a liability for which should be paid interest, and financial risk also exists. We believe that this formula requires perfection. For simplicity, suppose that own capital only includes own capital. If the company issued only ordinary shares, then there will be no fixed tax expenses in the form of dividends on privileged shares, as well as financial risks. But if privileged shares are also issued, then the obligation arises on issuing the dividends at an unchanged rate. Therefore, there will be a financial risk for holders of ordinary shares. For example, if the company's assets are 2 million GEL, which is financed by own capital, the financial leverage is equal to one and there is no risk. But if privileged shares in the amount of half a million GEL are issued within the share capital, then the shareholders of ordinary shares will be at risk for dividends, that is not shown in the formula of the financial leverage (3) presented above.

Based on the above, the formula (3) should be corrected as follows:

$$
\mathrm{Fl}_{1}=\text { Assets/( own capital }- \text { privileged share capital) }
$$




$$
\mathrm{Fl}_{2}=\text { Liabilities/(own capital- privileged share capital) }
$$

Indeed, according to the formula, the financial leverage ratio will be more than one: $2 /(2-0,5)=1,33$

$$
\mathrm{Fl}_{3}=\text { operating profit/earnings before tax }
$$

$$
\text { Fl4 (Capital leverage })=\frac{\text { Own capital }+ \text { long term loans }}{\text { own capital-privileged share capital }}
$$

$$
\text { Fl5 (total leverage })=\frac{\text { Own capital }+ \text { own turnover of funds }+ \text { long term loans }}{\text { own capital }+ \text { Long term loans }}
$$

$$
\text { Financial leverage level }=\frac{\% \text { change in net profit }}{\% \text { change in operating profit }}
$$

$$
\text { General leverage of interest }=\frac{\text { loan interest rate }+ \text { dividend of privileged share }}{\text { operating profit }}
$$

$$
\text { Financial leverage level }=\frac{\% \text { change in net profit }}{\text { income percentage change }}
$$

\begin{tabular}{|c|c|c|c|}
\hline Indicators & $\begin{array}{l}\text { N1 } \\
\text { Enterprise }\end{array}$ & N2 Enterprise & N3 Enterprise \\
\hline Assets & 40000 & 40000 & 40000 \\
\hline Share capital in privileged shares (privileged own capital) & 15000 & 10000 & 12000 \\
\hline Share capital in ordinary shares (1000 pcs) & 25000 & 25000 & 18000 \\
\hline own capital & 40000 & 35000 & 30000 \\
\hline Loans are taken & - & 5000 & 10000 \\
\hline Total capital & 40000 & 40000 & 40000 \\
\hline Income from sale & 15000 & 15000 & 15000 \\
\hline Variable costs & $(6000)$ & $(8000)$ & $(4000)$ \\
\hline fixed costs & $(6000)$ & $(4000)$ & $(8000)$ \\
\hline Total operating costs & 12000 & 12000 & 12000 \\
\hline Operating profit & 3000 & 3000 & 3000 \\
\hline Loan interest costs $(18 \%)$ & & $(900)$ & $(1800)$ \\
\hline Profit before tax & 3000 & 2100 & 1200 \\
\hline Income tax $(15 \%)$ & $(450)$ & $(315)$ & $(180)$ \\
\hline Net profit & 2550 & 1785 & 1020 \\
\hline Privileged shares dividends (12\%) & $(1800)$ & $(1200)$ & $(1440)$ \\
\hline Earnings per ordinary share & & & \\
\hline Coefficients of the leverage: & 0.75 & 0.59 & -- \\
\hline 1. Operating leverage (fixed costs/variable costs) & 1 & 0,5 & 2.0 \\
\hline 2. Financial leverage (assets/own capital) & 1 & 1,14 & 1,33 \\
\hline 3. Financial leverage (assets/(own capital - privileged share capital) & 1,6 & 1.6 & 2.22 \\
\hline 4. Financial leverage [operating profit /profit before tax & 1.0 & 1.43 & 2.50 \\
\hline 5. FL (liabilities/own capital) & 0 & 1.14 & 0.33 \\
\hline 6. FL [liabilities/(own capital - privileged share capital)] & 0.6 & 0,20 & 0.56 \\
\hline 7. Percent leverage (percent costs/operating profit) & 0 & 0.30 & 0.60 \\
\hline 8. Total percent leverage [ $\%$ costs+privileged sharesdividends /operating profit & 0.60 & 0.70 & 1.08 \\
\hline
\end{tabular}

\subsection{Comparative Analysis of the Leverage Indicators}

First of all, it should be noted that in economics there is a need for an agreement that the risk assessment ratio must be higher than one. We share the concept that when the risk ratio is higher than one, so there is a risk. There is no risk up to one. This approach leads to an understanding of risk factors and their practical application. However, all the coefficients of leverage do not meet this requirement.

Table 1. Comparison of the financial leverage coefficients (In GEL)

The first table of data analysis shows that in the the first plant, although the financial leverage is equal to one and there is no risk for ordinary shareholders, because this enterprise does not use loans, but given the fact that privileged shareholders have a guaranteed dividend rate, there is a risk for ordinary shareholders in all enterprises. The same 
situation is in the rest of the enterprises. In the third enterprise, there is no net profit for the dividend on the ordinary shares at all. Therefore, if the enterprise has issued privileged shares, should be used the third, 6th and 8th ratios.

Comparative analysis shows that from the financial leverage coefficients: the second, third and fourth - respond to the general requirement of the financial leverage index: they show the risks if the indicator exceeds one. And, the 5th, 6th, 7 th and 8 th coefficients above 0,5 are already dangerous. The same table shows that there is is no direct correlation between the operating leverage and financial leverage coefficients. There may be only one type of risk, other is not and the opposite.

In addition, we note that financial risks are not only for shareholders. If the company is not profitable, shareholders will remain without dividends. As a rule, net profit is the difference between annual profits (i. e. - Earning before tax) and profit tax. Obviously, if the annual profit does not exist, the shareholders will not have any income. Therefore, management must first manage and control the risks of annual profits.

The comparative analysis of the six financial leverage ratios presented in the same first table suggests that, of the financial leverage ratios, the overall leverage ratios of the own capital ratio reduced by assets and privileged share capital and the ratio of operating and annual profit and interest clearly indicate the presence of risks, when their value is more than one. In our opinion, the general indicator of the financial leverage should be chosen, which can be used for general evaluation of financial risk.

Due to the fact that the final financial result of the enterprise is profit and all the indicators influence it, as a general indicator of financial leverage, we recognize the operating profit and annual profit coefficient (OP/P). Net profit is not the final financial result of the company's work because profit tax does not depend on the quality of work and activity of enterprises.

\subsection{Multifactor Model of Financial Leverage}

It is known two approaches to building a factor model: Altman and Dupont. The Altman method - the line of factors is based on the sum of factors. Beta coefficients are calculated for each factor index based on the correlation between they (1968).

DuPont method is represented by a multiple of factors line, which is based on the sequence of the formation of the factor- indicators used (1912). This method was first used by the company DuPont (1912) by the management of the 1920s. Therefore, it is called the Dupontian method. Using the concept of the DuPont Method, we have developed the following multi-factors model of financial leverage.

First, it is necessary to determine, which of them $\mathrm{A} / \mathrm{OwC}$ and $\mathrm{OP} / \mathrm{P}$ coefficients is an independent variable. Based on the substantiation of the causal relationship, we can be concluded that the ratio of assets and own capital characterizes risks arising from liabilities and, therefore, it affects on the operating profits and profit margins coefficients OP/P. So, this is a dependent indicator.

As we have already mentioned, in our opinion OP/P is the most common result of the indicators of financial leverage.

Therefore, we have created a five-factor model of this indicator. The factors-line must be based on the existing logical connection between indicators.

$$
\frac{\mathrm{OP}}{\mathrm{P}}=\frac{\mathrm{OP}}{\mathrm{S}} * \frac{\mathrm{S}}{\mathrm{PS}} * \frac{\mathrm{PS}}{\mathrm{A}} * \frac{\mathrm{A}}{\mathrm{OwC}} * \frac{\mathrm{OwC}}{\mathrm{P}} ; \quad \text { where, }
$$

$\mathrm{OP} / \mathrm{P}$ - the ratio of operating profit and annual profit (profit before tax) - In our opinion, it is a general index of financial leverage;

$\mathrm{OP} / \mathrm{S}$ - the ratio of operating profit and sale - Its growth indicates that the risk of sales increases, which increases the financial risks;

$\mathrm{S} / \mathrm{PS}$ - the ratio between sale and profit of sale - its growth indicates that increases risks in the use of manufacturing expenses;

PS/A - the ratio of profit of sale and total assets - its growth indicates that increases risks of asset aging and insufficiency;

$\mathrm{A} / \mathrm{C}$ - the ratio of assets and own capital - its growth means that rising credit and interest risks;

$\mathrm{C} / \mathrm{P}$ - the ratio of $\mathrm{OwC}$ and profit before tax - its growth means that decreases the economic effect of own capital, thus the risks of paying dividends are rising.

So, The higher the factor ratios, the financial risks will increase.

\section{Empirical Value of the Factor Model of Financial Leverage}

The method of absolute difference is used to measure the influence of factors based on the above-mentioned financial leveraging factor model. For the empirical testing of the model, we have used the financial information of Georgian wine company JSC, "Teliani Valley" for the period 2010-2017.

As of 2017 JSC, "Teliani Valley” assets involves 108 million GEL and has deposited approximately 535 million usual 
shares, with the nominal price of one -1 tetri (we consider such low price is not serious). While the last three years the Company has become unprofitability. Thus, the issues of profitability analysis of this company became very relevant. At present time "Teliani Valley" is a big company and it has five affiliates; produces a full spectrum of Georgian traditional wine, also products received by a mixture of Georgian and foreign wines as well. As of 2017 JSC, "Teliani Valley" assets involves 108 million GEL and has deposited approximately 535 millions usual shares. He always had a high image. While the last three years the Company has become unprofitable. Thus, the issues of financial results analysis of this company became very relevant.(Izolda Chiladze. 2018. p. 15). It was very interesting for us to study the dynamics of financial leverage indicators in the same period (see table 2).

Table 2. Financial leverage coefficients of company JSC Teliani Valley

\begin{tabular}{lcccccccc}
\hline Financial leverage coefficients & 2010 & 2011 & 2012 & 2013 & 2014 & 2015 & 2016 & 2017 \\
\hline 1. Assets/own capital & 1.29 & 2.26 & 1.80 & 1.89 & 2.00 & 2.12 & 3.56 & 2.80 \\
2. Liabilities/own capital (L/OwC) & 0.60 & 1.26 & 0.86 & 1.16 & 1.00 & 1.19 & 2.56 & 1.80 \\
3. Operational profit/annual profit & 4.68 & 2.93 & 1.49 & 1.27 & 1.72 & -4.55 & -6.55 & -0.33 \\
4. Interest expenses/operational profit & 0.79 & 0.61 & 0.28 & 0.21 & 0.25 & 0.41 & 0.54 & -0.72 \\
5.\%change in net profit /\% change in EBIT & - & 2.90 & 8.07 & 1.21 & 15.0 & -0.78 & -2.28 & -3605 \\
6. \% change in EBIT / \% change in Sale & - & 1.14 & 1.03 & 2.50 & 0.25 & 6.00 & -10.0 & -1.55 \\
\hline
\end{tabular}

As shown in the second table, the financial leverage ratios are very high. Based on the trends of financial leverage ratios, we may conclude that leverage coefficients should not rise above the average level of 2010-2014. In particular, there may be a minimum level of leverage ratios:

1. Assets/own capital $-(1.29+2.26+1.80+1.89+2) / 5=1.85$

2. Liabilities/own capital $-(0,60+1.26+0.86+1.16+1.0) / 5=0.98$

3. Operational profit/annual profit $-(4.68+2.93+1.49+1.27+1.72) / 5=2.42$

4. Interest expenses/operational profit $-(0.79+0.61+0.28+0.21+0.25) / 5=0.43$

In the analytical company, negative financial leverage has been as of 2015. In this case, there is no risk, because the danger has become reality. Such negative financial results may be caused by external subjective factors.

The named company is unprofitable from 2015. Therefore, the indicators of 2013-2014 are taken for the purpose of showing the factor analysis method(see Table 3). In order to measure the impact of factors, the method of absolute variation of the Eliminator methodology is used.

Table 3. Influence of the change in factors affecting the financial leverage aviation

\begin{tabular}{lllll}
\hline Indicators & 2013 & 2014 & Deviation & $\begin{array}{l}\text { Factors } \\
\text { Influence }\end{array}$ \\
\hline OP/P & 1.267 & 1.722 & +0.455 & - \\
The factors: & & & & \\
I. OP/S & 0.1241 & 0.1405 & +0.0164 & +0.167 \\
II. S/PS & 2.0349 & 1.8888 & -0.1461 & -0.103 \\
III. PS/A & 0.5142 & 0.4294 & -0.0848 & -0.220 \\
IV. A/OwC & 1.8945 & 2.0016 & +0.1071 & +0.063 \\
V. OwC/P & 5.1501 & 7.5508 & +2.4007 & +0.548 \\
& & & & -0.455 \\
\hline
\end{tabular}

Basic row $=0.1241 * 2.0349 * 0.5142 * 1.8945 * 5.1501=1.267$

Influence of the first factor $=(+0.0164) * 2.0349 * 0.5142 * 1.8945 * 5.1501=+0.167$

Influence of the second factor $=0.1405 *(-0.1461) * 0.5142 * 1.8945 * 5.1501=-0.103$

Influence of the third factor $=0.1405 * 1.8888 *(-0.0848) * 1.8945 * 5.1501=-0.220$

Influence of the fourth factor $=0.1405 * 1.8888 * 0.4294 *(+0.1071) * 5.1501=+0.063$

Influence of the fifth factor $=0.1405 * 1.8888 * 0.4294 * 2.0016 *(+2.4007)=+0.548$

$$
+0.455
$$

Thus, the financial risk of 2014 increased by 0.445 points or $36 \%$ compared to the previous year. The increase in the first factor by 0.0164 points has increased the financial risk by 0.0167 points and so on (Table 3 ). from the five factors 
shown, second and third factors have reduced financial risks, which is a positive occurrence. And three factors increased it. In this case, the company's management should take special measures to increase the share of equity in the assets and refuse to receive loans. It is also important to monitor operational risks for use expenses more effectively.

\section{Conclusions and Recommendations}

Thus, financial risk management the governors of the enterprises is necessary for raising profitability and financial stability. The essence and indicators of financial leverage known in the literature were studied in the article. Among them, one of the general indicators was selected - operating profit ratio with annual profits (profit before tax). And its five-factor model was created. It can be used in all sectors of the economy, except for commercial banks. The results of the analysis of the experimental enterprise indicate that the management of the enterprise does not control financial risks at all, which is a serious deficit of management quality. Practical use of the financial leverage factor model presented in the study will help the enterprise managers to easily identify the causes of risks and take adequate measures to avoid financial instability in a timely manner.

\section{Reference}

Altman E.I. (1968). Financial Ratios: Discriminant Analysis and the Prediction of Corporate Bankruptcy.The Journal of Finance, 23(4), 589-609.https://doi.org/10.1111/j.1540-6261.1968.tb00843.x

Charles, H. G. (2009). Financial Reporting and Analysis, http://zu.edu.jo/UploadFile/Library/E_Books/Files/LibraryFile_91615_13.pdf

Chiladze, I. (2017). Factor Analysis Aspects of the Enterprise`s Operating Leverage. Journal of Applied Finance and Accounting. 3(1),75-82.https://doi.org/10.11114/afa.v3i1.2050

Chiladze, I. (2018). Theoretical and Practical Aspects of Profitability Factorial Analysis. Journal: Science and Studies of Accounting and Finance: Problems and Perspectives, 12(1), 12-18.https://doi.org/10.15544/ssaf.2018.02

Dilip, K. G., Arun, J. P., \&Dipasri G. (2010). Leverage and Asset Allocation Under Capital MarketDistortion. International Journal of Business, 15(4), 459-471. http://www.craig.csufresno.edu/ijb/Volumes/Volume\%2015/V154-7.pdf

DuPont Analysis Method (1912).https://en.wikipedia.org/wiki/DuPont_analysis

Ivo, W. (2014).Corporate Finance (3td Edition), Prentice Hall. http://www.afajof.org/SpringboardWebApp/userfiles/afa/file/Free\%20Textbooks/Welch-ed1.pdf

James, C., Van, H., John, M.,\&Wachowicz, J. (2008). Fundamentals of Financial Management.thirteenth edition, Prentice Hall. https://yamanfc.files.wordpress.com/2015/01/fundamentals-of-financial-management.pdf

Pamela, P. D., \&Frank J. F. (2012). Analysis of Financial Statements. Third Edition, Published in Canada. https://www.amazon.com/Analysis-Financial-Statements-Pamela-Peterson/dp/1118299981

Subramanyam, K. R.,\&Joan, J. W. (2009). Financial Statement Analysis(10td Edition). https://madnanarshad.files.wordpress.com/2014/02/fsa-by-john-j-wild-10th-wdition.pdf

Thomas, R. I. (2009). Financial Statement revised and expanded edition. https://www.amazon.com/dp/1601630239/ref=sspa_dk_detail_2?psc=1

Yinka, M. S., Taibat, A. A., \& Bamidele, A. O. (2018).Enterprise Risk Management and performance of Selected Listed Consumer Goods Companies in Nigeria. Journal Applied Finance and Accounting,4(1), 112-119.

\section{Copyrights}

Copyright for this article is retained by the author(s), with first publication rights granted to the journal.

This is an open-access article distributed under the terms and conditions of the Creative Commons Attribution license which permits unrestricted use, distribution, and reproduction in any medium, provided the original work is properly cited. 